\title{
Physical Quality of a Typic Hapludult Soil Under Forest Leguminous Trees and Pasture
}

\author{
David Silva Gomes $^{1}$ (D), Cláudio Roberto Marciano ${ }^{1}$ (D), Lucas Luís Faustino ${ }^{1}$ \\ ${ }^{1}$ Universidade Estadual do Norte Fluminense Darcy Ribeiro - UENF, Campos dos Goytacazes/RJ, Brasil
}

\begin{abstract}
Revegetation with leguminous trees has been used to recover degraded areas. This study aimed to evaluate the physical quality of a Typic Hapludult soil under secondary forest, pasture and three leguminous tree species: Acacia (Acacia auriculiformis), Sabia (Mimosa caesalpiniaefolia) and Inga (Inga spp.), in Conceição de Macabú County, Rio de Janeiro State, Brazil. Soil samples from the $0-0.10 \mathrm{~m}$ and $0.10-0.20 \mathrm{~m}$ layers were collected and analyzed in July, 2015. Lower bulk density and higher total porosity and macroporosity values occurred under forest. The higher microporosities were associated with higher bulk densities and lower values of total porosity and macroporosity (pasture and Acacia). The soil under pasture, even when compacted, preserved the largest amount of mesopores, perhaps due to the fasciculate root system of these plants. It was concluded that revegetation leads to changes in the soil surface layer so that its physical attributes become similar to those found in the forest and differ from those of pasture, with an increase in quality to support forest ecosystem functioning.
\end{abstract}

Keywords: degraded area revegetation, soil compaction, soil total porosity, soil pore size distribution. 


\section{INTRODUCTION}

Brazilian soils are mostly highly weathered, with reduced chemical quality and a fragile macrostructure in the superficial layers. Under these conditions, organic matter, although at low levels, plays a central role in determining the quality of the soils considering both chemical and physical aspects (Bayer \& Mielniczuk, 2008).

Agricultural exploitation leads to the degradation of tropical soils, and in the north of Rio de Janeiro State this has been a consequence of the cutting and burning of forests and long periods of coffee and sugar cane monocultures using intensive mechanization and fire in pastures (Gama-Rodrigues et al., 2008).

The two main mechanisms that lead to reduction of soil quality are compaction (Reichert et al., 2007) and loss of organic matter (Bayer \& Mielniczuk, 2008). While compaction mainly affects physical aspects, the degradation of organic matter has an effect on chemical and physical aspects, since organic matter is perhaps the main factor responsible for the structure of the superficial soil layer.

Implantation of forest systems with leguminous species is one of the most implemented strategies to recover degraded areas, since in addition to improving nutrient availability, the increase in organic matter content increases biological activity and improves physical attributes (Gama-Rodrigues et al., 2008).

Soil attributes from which inferences about soil quality can be made are called soil quality indicators. Among physical indicators, we can highlight (Ferreira, 2010; Libardi, 2010; Silva et al., 2010): (i) those related to the soil matrix; (ii) those related to the structure - or spatial arrangement of soil particles; (iii) those related to the soil's mechanical resistance; (iv) those related to the amount and energy of water retained in the soil; and (v) those related to the dynamic processes in the porous space of the soil.

Thus, the objective of this study was to evaluate the physical quality of a Typic Hapludult soil under secondary forest (popularly known in Brazil as capoeira), leguminous tree species and pasture on a hillside in the Municipality of Conceição de Macabú, RJ, Brazil.

\section{MATERIAL AND METHODS}

The study area is located in the municipality of Conceição de Macabú, North of Rio de Janeiro, at Carrapeta Farm $\left(21^{\circ} 37^{\prime} \mathrm{S}\right.$ and $\left.42^{\circ} 05^{\prime} \mathrm{W}\right)$. According to the Köppen classification, the region's climate is Am type, hot and humid, with an average temperature of $26{ }^{\circ} \mathrm{C}$ and an average annual rainfall of $1400 \mathrm{~m}$ (Gama-Rodrigues et al., 2008). The relief is strong wavy, with a slope around $0.35 \mathrm{~m} \mathrm{~m}^{-1}$. The soil is an Argissolo Vermelho-Amarelo Distrófico according to the Brazilian Soil Classification System (Embrapa, 2013), or a Typic Hapludult soil according to the American Soil Classification System (Soil Survey Staff, 2014).

The experimental area consists of laterally adjacent vegetation cover at the same elevation: Acacia auriculiformis (Acacia); Mimosa caesalpinifolia (Sabia); Inga spp. (Inga); degraded pasture (pasture); and secondary forest (capoeira). The secondary forest has not been managed and trees have not been removed for over 50 years; the pasture dates back to the 1930s; and the three leguminous species were planted in 1998 in plots of $1500 \mathrm{~m}^{2}(75 \mathrm{~m} \times 20 \mathrm{~m})$. Soil samples from 0-0.10 m and $0.10-0.20 \mathrm{~m}$ depth layers were collected in July 2015, with deformed and undeformed structures, at six points (replications) set $5 \mathrm{~m}$ from each other along the steepest slope in each plot.

Deformed samples were air dried, sifted and used for chemical characterization according to the methodologies reported by Gama-Rodrigues et al. (2008). Particle size analysis was performed using the pipette method in the same samples, with adaptations according to the method described by Valicheski et al. (2011). The chemical and particle size results are presented in Table 1. Undisturbed samples collected in $100 \mathrm{~mL}$ metal rings were used to determine soil bulk density (BD), total porosity (TP), and the soil water retention curve based on Libardi (2010).

In order to determine the water retention curve in the soil, the samples were saturated and submitted to tensions of $1,3,6$ and $10 \mathrm{kPa}$ in porous plate funnels, and of 33, 100, 500 and $1500 \mathrm{kPa}$ in Richards pressure chambers. After reaching equilibrium, the samples were weighed, dried at $105^{\circ} \mathrm{C}$ for $48 \mathrm{~h}$, and then weighed again to obtain the volumetric water content $\left(\theta, \mathrm{m}^{3} \mathrm{~m}^{-3}\right)$. The results were adjusted to the Van Genuchten (1980) Equation 1: 
Table 1. Granulometric composition (sand, silt and clay) and chemical attributes (hydrogen potential - $\mathrm{pH}$, organic carbon - OC, sum of bases - SB, and effective and potential cation exchange capacity - $\mathrm{CEC}_{\mathrm{ef}}$ and $\mathrm{CEC}_{\mathrm{pH}=7}$, respectivly) of a Typic Hapludult soil under different vegetation cover in the 0-0.10 m, 0.10-0.20 m and 0-0.20 m (average) layers in Conceição de Macabú, RJ, Brazil.

\begin{tabular}{|c|c|c|c|c|c|c|c|c|}
\hline \multirow{3}{*}{$\begin{array}{l}\text { Vegetation } \\
\text { cover }\end{array}$} & Sand & Silt & Clay & pH & OC & SB & $\mathrm{CEC}_{\text {ef }}$ & $\mathrm{CEC}_{\mathrm{pH}=7}$ \\
\hline & \multicolumn{3}{|c|}{-------- $\left(\mathrm{g} \mathrm{kg}^{-1}\right)$------- } & $\left(\mathrm{H}_{2} \mathrm{O}\right)$ & $\left(\mathrm{mg} \mathrm{kg}^{-1}\right)$ & \multicolumn{3}{|c|}{--------( $\left(\mathrm{cmol}_{\mathrm{c}} \mathrm{kg}^{-1}\right)-------$} \\
\hline & \multicolumn{8}{|c|}{ 0-0.10 m layer } \\
\hline Capoeira & 640.0 & 85.5 & 274.5 & 4.22 & 18.8 & 0.79 & 1.9 & 8.6 \\
\hline Acacia & 627.1 & 70.1 & 302.8 & 4.48 & 14.6 & 2.14 & 2.5 & 8.9 \\
\hline Inga & 610.8 & 93.1 & 296.1 & 4.22 & 13.9 & 0.90 & 1.9 & 7.5 \\
\hline Sabia & 603.8 & 96.8 & 299.4 & 4.26 & 16.0 & 1.05 & 2.2 & 8.8 \\
\hline Pasture & 637.6 & 90.7 & 271.7 & 4.26 & 13.1 & 0.41 & 1.3 & 6.8 \\
\hline \multirow[t]{2}{*}{ Mean } & 623.8 & 87.2 & 288.9 & 4.29 & 15.3 & 1.06 & 2.0 & 8.1 \\
\hline & \multicolumn{8}{|c|}{$0.10-0.20 \mathrm{~m}$ layer } \\
\hline Capoeira & 598.5 & 93.8 & 307.6 & 4.12 & 12.2 & 0.30 & 1.4 & 7.8 \\
\hline Acacia & 510.0 & 96.0 & 394.1 & 4.34 & 11.1 & 0.79 & 1.7 & 7.4 \\
\hline Inga & 535.7 & 108.4 & 356.0 & 4.28 & 10.8 & 0.40 & 1.5 & 7.0 \\
\hline Sabia & 515.4 & 111.7 & 372.9 & 4.22 & 11.9 & 0.46 & 1.7 & 7.1 \\
\hline Pasture & 533.3 & 110.2 & 356.5 & 4.18 & 11.3 & 0.16 & 1.1 & 7.2 \\
\hline Mean & 538.6 & 104.0 & 357.4 & 4.22 & 11.4 & 0.42 & 1.5 & 7.3 \\
\hline
\end{tabular}

$\theta=\theta r+\frac{\theta_{s}-\theta_{r}}{\left(1+\alpha \cdot \tau^{n}\right)^{m}}$

Where: $\theta_{\mathrm{s}}$ is the saturated water content $\left(\mathrm{m}^{3} \mathrm{~m}^{-3}\right) ; \theta_{\mathrm{r}}$ is the residual water content $\left(\mathrm{m}^{3} \mathrm{~m}^{-3}\right) ; \alpha\left(\mathrm{kPa}^{-1}\right), \mathrm{m}$ and $\mathrm{n}$ (dimensionless) are empirical parameters of the model. To obtain the equations, $\theta_{s}$ was assumed to correspond to total porosity, $\mathrm{m}$ was considered to be dependent on $\mathrm{n}(\mathrm{m}=1-1 / \mathrm{n})$, and $\theta_{\mathrm{r}}, \alpha$ and $\mathrm{m}$ were estimated with the help of the 'solver' add-in of the Microsoft Office Excel 2010 program using the method of least squares.

The retention curve was used to evaluate pore distribution by size, which has been considered a more usual or traditional scale with the macropore and micropore classes being delimited by a diameter of $50 \mu \mathrm{m}$ (corresponding to tension of $6 \mathrm{kPa}$ ); and a more detailed scale with the macropore, mesopore, micropore and cryptopore classes delimited by the diameter values of 100, 30 and $0.2 \mu \mathrm{m}$, respectively (corresponding to tensions of 3,10 and $1500 \mathrm{kPa}$ ). The pore volume in each of the size classes above was determined by the difference between water content at the tensions that delimit them, obtained by the equation adjusted for the retention curve.

Similar to other studies conducted in this area (Gama-Rodrigues et al., 2008; Costa et al., 2014), the statistical analysis was carried out assuming a completely randomized design, although the basic precepts of experimental statistics were not met with rigor (randomization, repetition and local control). The absence of these precepts was compensated for based on the collection points, which were at the same altitude and presented pedological uniformity between the plots, as shown by the morphological aspects of the profile. The treatments were also considered in a split-splot scheme with the five vegetation covers in the plots and the two sampling layers in the subplots, in addition to the six collection points as replications. The statistical analysis was performed using the "Assistat" software, in which the means comparison was carried out by the Tukey test at $5 \%$ of probability. Pearson's linear correlation coefficients between the various physical variables were obtained from the Microsoft Office Excel 2010 spreadsheet.

\section{RESULTS AND DISCUSSION}

The granulometric composition for both studied layers showed no differences between the vegetation covers for the sand and clay fractions (Table 1). For the silt fraction, the lower levels are consistent with those usually observed in highly weathered tropical soils (Ferreira, 2010), and although significant, the maximum difference observed between the vegetation covers considering the mean of both layers was very small, 
being $2.13 \%$ (or $21.3 \mathrm{~g} \mathrm{~kg}^{-1}=104.3-83.0$ ). As texture is one of the most stable attributes of soil (Ferreira, 2010), the different granulometric fraction contents are not adjustable in terms of their use or management (at least within the timeframe of a few years or even a few decades). Therefore, any differences observed in the analysis of variance of the granulometric composition would not be a consequence of the treatments, but rather of pre-existing pedological variations between the experimental units.

In the present case, the low silt levels (negligible in terms of creating differences in soil behavior or in other chemical or physical attributes), and the absence of differences between the vegetation covers with respect to sand and clay fractions, reveal great pedological uniformity between the plots. This allows performing analysis of variance considering treatments in a completely randomized design despite the basic precepts of experimental statistics not having been met. Comparing the layers, the sand content was higher and the clay content was lower at 0-0.10 m than at $0.10-0.20 \mathrm{~m}$ (Table 1$)$. The studied soil class (Argissolo, or Ultisol) must obligatorily have a finer texture subsurface "Bt" horizon (Embrapa, 2013), but a textural gradient occurring between layers making up the surface " $\mathrm{A}$ " horizon is also frequent.
In relation to the soil bulk density results (Table 2), the secondary forest (capoeira) differed from the other plots, presenting the lowest means for both the $0-0.10 \mathrm{~m}$ and the $0.10-0.20 \mathrm{~m}$ layers $\left(1.114\right.$ and $1.093 \mathrm{Mg} \mathrm{m}^{-3}$, respectively). In relation to the other coverages, the highest averages occurred for Acacia with $1.386 \mathrm{Mg} \mathrm{m}^{-3}$ for the $0-0.10 \mathrm{~m}$ layer (not differing from pasture), and $1.474 \mathrm{Mg} \mathrm{m}^{-3}$ for the $0.10-0.20 \mathrm{~m}$ (in which Sabia was superior to Inga, which in turn did not differ from the pasture). Three distinct behaviors were noted in comparing the layers with respect to soil bulk density: no difference between layers occurred for capoeira; values from 0-0.10 $\mathrm{m}$ were lower than those from $0.10-0.20 \mathrm{~m}$ for the three planted forest coverages (Acacia, Inga and Sabia); and the opposite occurred for the pasture (values from 0-0.10 $\mathrm{m}$ were higher than from $0.10-0.20 \mathrm{~m}$ ). The figures found are slightly lower than those from 2010 for the same area (Gomes, 2014).

The behavior for total porosity (Table 2) for both layers was the inverse of that found for bulk density, with the highest values for Capoeira and the lowest for Acacia. Additionally, for both layers the intermediate position was occupied by the Sabia, Inga and pasture coverages. For the 0-0.10 m layer Inga and Sabia covers were equal to each other and superior to pasture, which did not differ from Acacia. For the 0.10-0.20 m

Table 2. Total porosity (TP), soil bulk density (BD) and pore size distribution $\left(^{*}\right)$ of a Typic Hapludult soil under different vegetation cover in 0-0.10 m, 0.10-0.20 m and 0-0.20 m (average), in Conceição de Macabú, RJ, Brazil.

\begin{tabular}{|c|c|c|c|c|c|c|c|c|}
\hline \multirow{3}{*}{$\begin{array}{l}\text { Vegetation } \\
\text { cover }\end{array}$} & BD & TP & macro1* & microl* & macro2* & meso & micro2* & Crypto \\
\hline & \multicolumn{8}{|c|}{ 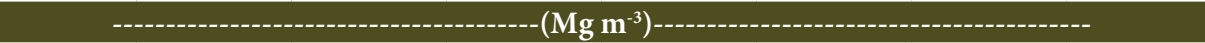 } \\
\hline & \multicolumn{8}{|c|}{ 0-0.10 m Layer } \\
\hline Capoeira & $1.114 \mathrm{cA}$ & $0.580 \mathrm{aA}$ & $0.398 \mathrm{aA}$ & $0.181 \mathrm{eB}$ & $0.357 \mathrm{aA}$ & $0.058 \mathrm{bB}$ & $0.024 \mathrm{~dB}$ & $0.140 \mathrm{~dB}$ \\
\hline Acacia & $1.386 \mathrm{aB}$ & $0.477 \mathrm{cA}$ & $0.249 \mathrm{dA}$ & $0.228 \mathrm{cB}$ & $0.221 \mathrm{dA}$ & $0.044 \mathrm{~dB}$ & $0.061 \mathrm{bB}$ & $0.150 \mathrm{bcB}$ \\
\hline Inga & $1.215 \mathrm{bB}$ & $0.542 \mathrm{bA}$ & $0.321 \mathrm{bA}$ & $0.221 \mathrm{~dB}$ & $0.286 \mathrm{bA}$ & $0.054 \mathrm{bcB}$ & $0.058 \mathrm{bB}$ & $0.144 \mathrm{cdB}$ \\
\hline Sabia & $1.255 \mathrm{bB}$ & $0.527 \mathrm{bA}$ & $0.294 \mathrm{cA}$ & $0.233 \mathrm{bB}$ & $0.261 \mathrm{cA}$ & $0.050 \mathrm{cdB}$ & $0.046 \mathrm{cB}$ & $0.170 \mathrm{aB}$ \\
\hline Pasture & $1.361 \mathrm{aA}$ & $0.486 \mathrm{cB}$ & $0.223 \mathrm{~dB}$ & $0.263 \mathrm{aA}$ & $0.177 \mathrm{eB}$ & $0.073 \mathrm{aA}$ & $0.081 \mathrm{aA}$ & $0.156 \mathrm{bA}$ \\
\hline \multirow[t]{2}{*}{ Mean } & 1.266 & 0.522 & 0.297 & 0.225 & 0.260 & 0.056 & 0.054 & 0.152 \\
\hline & \multicolumn{8}{|c|}{$0.10-0.20 \mathrm{~m}$ Layer } \\
\hline Capoeira & $1.093 \mathrm{dA}$ & $0.587 \mathrm{aA}$ & $0.355 \mathrm{aB}$ & $0.233 \mathrm{eA}$ & $0.301 \mathrm{aB}$ & $0.080 \mathrm{aA}$ & $0.049 \mathrm{cA}$ & $0.158 \mathrm{dA}$ \\
\hline Acacia & $1.474 \mathrm{aA}$ & $0.444 \mathrm{~dB}$ & $0.175 \mathrm{cB}$ & $0.268 \mathrm{cA}$ & $0.145 \mathrm{~dB}$ & $0.049 \mathrm{cA}$ & $0.080 \mathrm{aA}$ & $0.170 \mathrm{cA}$ \\
\hline Inga & $1.283 \mathrm{cA}$ & $0.516 \mathrm{bB}$ & $0.241 \mathrm{bB}$ & $0.275 \mathrm{bA}$ & $0.197 \mathrm{cB}$ & $0.068 \mathrm{bA}$ & $0.069 \mathrm{bA}$ & $0.182 \mathrm{bA}$ \\
\hline Sabia & $1.370 \mathrm{bA}$ & $0.483 \mathrm{cB}$ & $0.193 \mathrm{cB}$ & $0.290 \mathrm{aA}$ & $0.146 \mathrm{~dB}$ & $0.072 \mathrm{bA}$ & $0.070 \mathrm{bA}$ & $0.194 \mathrm{aA}$ \\
\hline Pasture & $1.271 \mathrm{cB}$ & $0.520 \mathrm{bA}$ & $0.265 \mathrm{bA}$ & $0.255 \mathrm{~dB}$ & $0.220 \mathrm{bA}$ & $0.070 \mathrm{bA}$ & $0.070 \mathrm{bB}$ & $0.160 \mathrm{dA}$ \\
\hline Mean & 1.298 & 0.510 & 0.246 & 0.264 & 0.202 & 0.068 & 0.068 & 0.173 \\
\hline
\end{tabular}

${ }^{*}$ ) Distribution in the usual scale: macropores (macrol: diameter $\geq 50 \mu \mathrm{m}$ ) and micropores (micro1: diameter $\leq 50 \mu \mathrm{m}$ ); Distribution on the detailed scale: macropores (macro2: diameter $\geq 100 \mu \mathrm{m}$ ), mesopores (meso: $100 \mu \mathrm{m} \geq$ diameter $\geq 30 \mu \mathrm{m}$ ), micropores (micro2: $30 \mu \mathrm{m} \geq$ diameter $\geq 0.2 \mu \mathrm{m}$ ) and cryptopores (crypto: diameter $\leq 0.2 \mu \mathrm{m}$ ); For each column (i.e. for each soil attribute), averages followed by the same capital letter (comparing the layers) or by the same lowercase letter (comparing the covers) do not differ from one another according to the Tukey test at $5 \%$ probability. 
layer, Inga and pasture were equal to each other and superior to Sabia. In comparing the layers, no total porosity difference was found for Capoeira, while, the porosity was higher in the $0.10-0.20 \mathrm{~m}$ layer than in the 0-0.10 m layer (greater surface compaction) for pasture, and it was lower in the 0.10-0.20 m layer than in the $0-0.10 \mathrm{~m}$ (less surface compaction) for three planted coverages (Acacia, Inga and Sabia).

The behavior described for bulk density and porosity show that: (i) preservation of the native vegetation allowed the secondary forest soil (capoeira) to maintain its original good structure, presenting the lowest bulk densities and higher total porosities in both layers; (ii) land use with pasture resulted in compacting both studied layers, which was more pronounced at $0-0.10 \mathrm{~m}$ possibly due to animal trampling and the direct impact of rainfall on the soil surface, which in the present case result in vegetation cover failures; and (iii) revegetation allowed the $0-0.10 \mathrm{~m}$ surface layer to present structure improvement over the $0.10-0.20 \mathrm{~m}$ layer, in which compaction remained severe, possibly as a consequence of the direct action of the roots and of litter deposition, thus a consequent increase of biological activity and organic matter content in the soil.

In analyzing an Alfisol (Argissolo Vermelho-Amarelo) under pasture and under native secondary forest, Santos et al. (2010) also found higher values of bulk density and lower total porosity values in the $0-0.10 \mathrm{~m}$ layer of the pasture area. In comparing the layers in the soil under forest they also found densification in the deepest layer of $0.20-0.30 \mathrm{~m}$, while in the soil under pasture, the highest compaction occurred in the superficial layer of $0-0.10 \mathrm{~m}$, which the authors attributed to animal trampling.

In an area of Inceptisols (Cambissolo Háplico) in the South of Rio de Janeiro State, Guareschi et al. (2014) found that secondary forests presented greater deposition of vegetation residue on the surface in comparison to pasture, and that intermediate ( 25 years) or advanced ( 60 years) regeneration stages favored the occurrence of lower bulk density and higher total soil porosity values.

Regarding pore distribution by size, higher macroporosity means (macro1 and macro2 - Table 2) were observed in the $0-0.10 \mathrm{~m}$ surface layer than in the 0.10-0.20 m layer for the four studied tree coverings (Capoeira, Acacia, Inga and Sabia). This could also be attributed to the presence of litter on the surface, which (as other studies carried out in the same area have shown) leads to increased biological activity (Manhães et al., 2009) and increases soil organic matter content (Rita et al., 2013). Altogether, this favors the formation of aggregates and the occurrence of larger diameter pores such as biopores and structural pores among neoformed aggregates.

The macropore values for pasture were higher in the 0.10-0.20 m layer than in the 0-0.10 m layer, showing that the aforementioned compaction of the superficial layer (by animal trampling, rain impact, etc.) occurs through a reduction in the volume of larger diameter pores, while the grass root system in the subsurface allows the formation/maintenance of macropores in the soil. The macroporosity showed a highly negative correlation with bulk density $(\mathrm{R}=-0.940$ for macro 1 and $\mathrm{R}=-0.898$ for macro 2 , which respectively compose the usual and detailed scales) and a highly positive correlation with total porosity $(\mathrm{R}=0.940$ and $\mathrm{R}=0.898$, also respectively for the aforementioned scales). Several studies have shown similar results showing that soil macroporosity is higher in conserved areas (under forest) than under both degraded pasture (Melloni et al., 2008; Calgaro et al., 2015) or intensive farming with either annual or perennial crops (Klein \& Libardi, 2002).

Comparing the vegetation covers in relation to macropores (Table 2), differences were observed in the superficial layer between all the covers in both allowed scales (macro1 and macro2) in the following order: Capoeira $>$ Inga $>$ Sabia $>$ Acacia $>$ Pasture (the exception was for macro1, with equality between Acacia and pasture). In the 0.10-0.20 m layer (also for both macro1 and macro2), the secondary forest maintained a higher value, superior to the others. However, the pasture went to the second position as a possible consequence of the grass root system performance in soil structuring. No changes were found in the ordering of the other three studied coverages, but the discrimination between the coverages was lower with Inga $>$ Sabia $=$ Acacia (Inga also did not differ from pasture for macro1). Calgaro et al. (2015) obtained similar results to those of the present study with the macroporosity of the soil under forest being higher in the $0-0.10 \mathrm{~m}$ layer than in the $0.10-0.20 \mathrm{~m}$, while the opposite occurred under grazing possibly as a result of the compaction of the surface layer. 
Regarding microporosity values on the more usual scale (micro1), differences between all vegetation covers were observed in both layers studied (Table 2). The pasture had the highest value and capoeira the lowest in the 0-0.10 m layer, with the other covers in intermediate positions (in this order: Sabia > Acacia > Inga). In the 0.10-0.20 m layer, micro1 values decreased in the following order: Sabia $>$ Inga $>$ Acacia $>$ Pasture $>$ Capoeira. Pasture assuming the fourth position close to that of capoeira (instead of the first position in the $0-0.10 \mathrm{~m}$ layer) is a possible consequence of the performance of the grass root system in the soil structuring in the 0.10-0.20 m layer, as suggested when discussing macroporosity.

In comparing the layers, the lowest micro1 values were observed in the $0-0.10-\mathrm{m}$ layer for all forest covers (Table 2). For this more usual pore size scale, microporosity (microl) presented a positive correlation with bulk density $(\mathrm{R}=0.634)$ and a negative correlation with total porosity $(\mathrm{R}=-0.634)$. As this microporosity behavior is opposite to that of the macroporosity, described above, the correlation between these variables (macro1 and micro1) was also negative $(\mathrm{R}=-0.860)$. This is justified by the fact that in denser and/or more compacted soils, there is greater proximity between the particles, consequently generating lower total porosity. Soil densification and/or compaction leads to the reduction of the macropore size, converting them into smaller pores. In these processes in which particles become closer, the volume of large pores eliminated is always greater than that of small pores created, so that statistically, significant differences between uses and managements are easily observed for macroporosity, but not for microporosity (Melloni et al., 2008; Nunes et al., 2010; Rocha et al., 2014). Significant differences for both pore size classes are usually restricted to cases where the management adopte is quite different, and with more severe impacts on compaction (Klein \& Libardi, 2002; Guimarães et al., 2014).

In relation to the detailed scale of pore distribution by size in the pasture soil, the comparison between layers revealed that the mesoporosity and cryptoporosity values did not differ between 0-0.10 $\mathrm{m}$ and 0.10-0.20 m depths (Table 2). However, microporosity (micro2) values were higher for the superficial layer (more compacted) than in the subsurface layer (less compacted), similar to what has already been described for soil bulk density and microporosity in the most usual scale (microl).
Thus, the micro2 showed a good positive correlation with the cited variables $(\mathrm{R}=0.667$ for bulk density and $\mathrm{R}=0.840$ for micro 1 ).

The highest amounts of mesopores, micropores and cryptopores for the four studied forest coverages occurred in the deepest layer $(0.10-0.20 \mathrm{~m})$. Other authors (Klein \& Libardi, 2002; Silva et al., 2005) have found similar results with increased amounts of pores in smaller diameter classes (micropores, cryptopores) in the more compacted or denser layers (generally corresponding to cohesive subsurface pedogenic horizons and/or of finer texture that accumulated illuvial clay during its formation).

For the detailed scale for pore size distribution, the results also reveal important edaphic differences between the studied plant coverings in addition to those already discussed for macroporosity (macro2). The lowest averages of both micropores and cryptopores for both studied layers were verified in the soil under capoeira (Table 2), coinciding with the lower bulk densities and higher total porosities. For the other covers, the micropores also have the highest averages associated with the highest bulk densities in both layers (Pasture and Acacia), however this association did not occur for cryptopores. For the detailed scale, it should be noted that micropores are responsible for water retention in the range available to plants between the tensions of 10 and $1500 \mathrm{kPa}$, so that the low occurrence of these pores in the soil under capoeira could (in a hastier analysis) indicate water limitations to the vegetation. However, according to a more focused approach regarding soil function in the ecosystem, it can be inferred that this fact may even be favorable to greater water availability for the plants over the medium term, since a greater macroporosity of the first layers would allow greater infiltration, and therefore greater water storage in subsurface horizons still reachable by the roots of perennial plants.

Continuing with the detailed scale of pore size, the comparison between plant covers shows that the proportion of mesopores in the pasture was higher than in the other coverings for the $0-0.10 \mathrm{~m}$ layer (Table 2). No differences for these were found between capoeira and Inga, between Inga and Sabia, or between Sabia and Acacia, with the mean value decreasing according to this respective order, and with differences occurring between Capoeira and Sabia and between Inga and Acacia. 
Analyzing the two plots with the highest compaction levels of the soil surface layer, the lower occurrence of mesopores was observed in Acacia, while the largest quantity of pores of this diameter range occurred in pasture. This shows that despite the compaction process, the grass root system acted to preserve mesopores, which according to Libardi (2010), are the main pores responsible for redistributing water in the soil profile. For the $0.10-0.20 \mathrm{~m}$ layer (also shown in Table 2), capoeira presented the highest values of mesopores and Acacia presented the lowest, while Inga, Sabia and pasture presented intermediate values with no differences between them. The mesopores generally show low correlation with the other physical attributes constant in Table 2, and the most notable were with bulk density and total porosity $(\mathrm{R}=-0.405$ and $\mathrm{R}=0.405$, respectively), and with macroporosity $(\mathrm{R}=0.345)$. Nevertheless, considering the order of the means according to the Tukey test letters, we can observe a certain similarity in behavior between the mesopores and the smaller diameter classes (micropores and cryptopores), since both are produced from larger pores (macropores) during the soil compaction process.

\section{CONCLUSION}

Soil under secondary forest presents good physical quality, with the $0-0.10 \mathrm{~m}$ and $0.10-0.20 \mathrm{~m}$ layers presenting low bulk density, high porosity and a high proportion of large pores, thus facilitating root system penetration, water infiltration and its storage in subsurface horizons still within the reach of the roots of tree species.

The soil under pasture, despite the adequate pore size distribution, presents low physical quality in the two studied layers, especially in the superficial layer, because it presented high bulk density and low total porosity.

In the Acacia revegetated area as succession to the pasture, both soil layers studied presented low physical quality showing the highest bulk density, lowest total porosity and a low proportion of large pores. This poor physical quality, even lower than that of pasture soil, may be partly due to some unidentified pedogenic process or old soil management event.

The revegetation of degraded areas with Inga and Sabia recovers the soil physical quality of $0-0.10$ m layer, since in the present case it allowed reaching intermediate bulk density and total porosity values when compared to those found for Capoeira and pasture.

\section{ACKNOWLEDGEMENTS}

Mr. José Laércio Paixão Flores, owner of Carrapeta Farm, for allowing the collection of soil samples and, even more, for revegetation of the studied area.

\section{FINANCIAL SUPPORT}

Received: 6 oct., 2017

Accepted: 26 oct., 2017

\section{CORRESPONDENCE TO}

\section{Lucas Luís Faustino}

Laboratório de Solos, Universidade Estadual do Norte Fluminense Darcy Ribeiro - UENF, Av. Alberto Lamego, 2000, Parque Califórnia, CEP 28013-602, Campos dos Goytacazes, RJ, Brasil e-mail: lucas.faustino@uenf.br

\section{FINANCIAL SUPPORT}

CAPES - Coordenação de Aperfeiçoamento de Pessoal de Nível Superior, (Grant/Award Number:) Fundação Carlos Chagas Filho de Amparo à Pesquisa do Estado do Rio de Janeiro, (Grant/Award Number:) - FAPERJ Fundação Carlos Chagas Filho de Amparo à Pesquisa do Estado do Rio de Janeiro, for the doctoral scholarship to third author; Coordenação de Aperfeiçoamento de Pessoal de Nível Superior, for the master scholarship to first author, and for the "PROAP" financial support to the Plant Production Post-graduation Program of UENF.

\section{REFERENCES}

Bayer C, Mielniczuk J. Dinâmica e função da matéria orgânica. In: Santos GA, Silva LS, Canellas LP, Camargo FO, editores. Fundamentos da matéria orgânica do solo: ecossistemas tropicais e subtropicais. Porto Alegre: Metrópole; 2008. p. 7-18.

Calgaro HF, Cambuim J, Silva AM, Alves MC, Buzetti S, Moraes MA et al. Distribuição natural de espécies arbóreas em áreas com diferentes níveis de antropização: atributos físicos do solo. Cultura Agronômica; 2015. p. 327-344. 
Costa MG, Gama-Rodrigues AC, Zaia FC, GamaRodrigues EF. Leguminosas arbóreas para recuperação de áreas degradadas com pastagem em Conceição de Macabu, Rio de Janeiro, Brasil. Scientia Forestalis 2014; 42(101): 101-112.

Empresa Brasileira de Pesquisa Agropecuária - Embrapa. Centro Nacional de Pesquisa de Solos. Sistema brasileiro de classificação de solos. 3. ed. Brasília: Embrapa; 2013.

Ferreira MM. Caracterização física do solo. In: Jong van Lier Q, editor. Física do solo. Viçosa: Sociedade Brasileira de Ciência do Solo; 2010.

Gama-Rodrigues EF, Gama-Rodrigues AC, Paulino GM, Franco AA. Atributos químicos e microbianos de solos sob diferentes coberturas vegetais no Norte do estado do Rio de Janeiro. Revista Brasileira de Ciência do Solo 2008; 32(4): 1521-1530. http://dx.doi.org/10.1590/S010006832008000400016.

Gomes DS. Estoque de carbono e nitrogênio em classes de agregados e em solos sob diferentes sistemas florestais no Norte Fluminense [monografia]. Campos dos Goytacazes: Universidade Estadual do Norte Fluminense Darcy Ribeiro; 2014.

Guareschi RF, Pereira MG, Menezes CEG, Anjos LHC, Correia MEF. Atributos químicos e físicos do solo sob pastagem e estádios sucessionais de floresta estacional. Revista de la Facultad de Agronomía 2014; 113: 47-56.

Guimarães GP, Mendonça ES, Passos RR, Andrade FV. Soil aggregation and organic carbon of oxisols under coffee in agroforestry systems. Revista Brasileira de Ciência do Solo 2014; 38(1): 278-287. http://dx.doi.org/10.1590/ S0100-06832014000100028.

Klein VA, Libardi PL. Densidade e distribuição do diâmetro dos poros de um latossolo vermelho, sob diferentes sistemas de uso e manejo. Revista Brasileira de Ciência do Solo 2002; 26(4): 857-867. http://dx.doi.org/10.1590/ S0100-06832002000400003.

Libardi PL. Água no solo. In: Jong van Lier, Q. editor. Física do solo. Viçosa: Sociedade Brasileira de Ciência do Solo; 2010.

Manhães CMC, Gama-Rodrigues EF, Moço MKS, GamaRodrigues AC. Biomassa de fauna do solo e da serapilheira em diferentes coberturas vegetais no Norte do Estado do Rio de Janeiro, Brasil. Revista Brasiseira de Agroecologia 2009; 4: 792-795.

Melloni R, Melloni EGP, Alvarenga MIN, Vieira FBM. Avaliação da qualidade de solos sob diferentes coberturas florestais e de pastagem no Sul de Minas Gerais. Revista
Brasileira de Ciência do Solo 2008; 32(6): 2461-2470. http://dx.doi.org/10.1590/S0100-06832008000600023.

Nunes LAPL, Dias LE, Jucksch I, Barros NF. Atributos físicos do solo em área de monocultivo de cafeeiro na zona da mata de Minas Gerais. Bioscience Journal 2010; 26: 71-78.

Reichert JM, Suzuki LEAS, Reinert DJ. Compactação do solo em sistemas agropecuários e florestais: identificação, efeitos, limites críticos e mitigação. In: Ceretta CA, Silva LS, Reichert JM, editores. Tópicos ciência do solo. Vol. 5. Viçosa: Sociedade Brasileira de Ciência do Solo; 2007.

Rita JCO, Gama-Rodrigues AC, Gama-Rodrigues EF, Zaia FC, Nunes DAD. Mineralization of organic phosphorus in soil size fractions under different vegetation covers in the north of Rio de Janeiro. Revista Brasileira de Ciência do Solo 2013; 37(5): 1207-1215. http://dx.doi.org/10.1590/ S0100-06832013000500010.

Rocha OC, Guerra AF, Ramos MLG, Oliveira AS, Bartholo GF. Qualidade físico-hídrica de um latossolo sob irrigação e braquiária em lavoura de café no cerrado. Coffee Science 2014; 9: 516-526.

Santos JT, Andrade AP, Silva IF, Silva DS, Santos EM, Silva APG. Atributos físicos e químicos do solo de áreas sob pastejo na Micro Região do Brejo Paraibano. Ciência Rural 2010; 40(12): 2486-2492. http://dx.doi.org/10.1590/ S0103-84782010001200008.

Silva AP, Tormena CA, Dias MS Jr, Imhoff S, Klein VA. Indicadores da qualidade física do solo. In: Jong Van Lier Q, editor. Física do solo. Viçosa: Sociedade Brasileira de Ciência do Solo; 2010. p. 241-281.

Silva MAS, Mafra AL, Albuquerque JA, Bayer C, Mielniczuk J. Atributos físicos do solo relacionados ao armazenamento de água em um Argissolo Vermelho sob diferentes sistemas de preparo. Ciência Rural 2005; 35(3): 544-552. http:// dx.doi.org/10.1590/S0103-84782005000300009.

Soil Survey Staff. Keys to soil taxonomy. 12th ed. Washington: USDA-Natural Resources Conservation Service; 2014.360 p.

Valicheski RR, Marciano CR, Peçanha AL, Bernardes RS, Monnerat PH. Estado nutricional do coqueiro cultivado em solos submetidos a diferentes níveis de compactação e umidade. Revista Brasileira de Engenharia Agrícola e Ambiental 2011; 14: 45-50.

Van Genuchten MT. A closed form equation for predicting the hydraulic conductivity of unsaturated soils. Soil Science Society of America Journal 1980; 44(5): 892-898. http:// dx.doi.org/10.2136/sssaj1980.03615995004400050002x. 